Fixed Point Theory, 21(2020), No. 1, 47-66

DOI: $10.24193 /$ fpt-ro.2020.1.04

http://www.math.ubbcluj.ro/ ${ }^{\text {nodeacj/sfptcj.html }}$

\title{
ABSTRACT MEASURES OF NONCOMPACTNESS AND FIXED POINTS FOR NONLINEAR MAPPINGS
}

\author{
DAVID ARIZA-RUIZ* AND JESÚS GARCIA-FALSET** \\ *Departamento de Análisis Matemático, Universidad de Sevilla, \\ Apdo. 1160, 41080-Sevilla, Spain \\ E-mail: dariza@us.es \\ ** Departament d'Anàlisi Matemàtica, Universitat de València, \\ Dr. Moliner 50, 46100, Burjassot, València, Spain \\ E-mail: garciaf@uv.es \\ Corresponding author
}

\begin{abstract}
In this paper, we study the existence of fixed points for a mapping by using abstract measures of noncompactness. Thus, we can obtain some generalizations of Darbo and Sadovskiı̌'s theorems and we also give a characterization for the existence of fixed points of a mapping which is not necessarily continuous. Finally, we solve an open problem proposed by I.A. Rus in 2001.
\end{abstract}

Key Words and Phrases: Measure of noncompactness, fixed points, continuous mappings.

2010 Mathematics Subject Classification: 47H09, 47H10, 47H30.

Acknowledgements. Part of this work was carried out while the first author was visiting Department of Mathematical Analysis of the University of Valencia. He is grateful to the department and the staff for the warm hospitality.

The research of the first author has been partially supported by MTM 2015-65242C2-1-P and P08-FQM-03453. The second author has been partially supported by MTM 2015-65242-C2-2-P.

\section{REFERENCES}

[1] A. Aghajani, R. Allahyari, M. Mursaleen, A generalization of Darbo's theorem with application to the solvability of systems of integral equations, J. Comput. Appl. Math., 260(2014), 68-77.

[2] J. Appell, Measure of noncompactness, condensing operators and fixed points: An applicationoriented survey, Fixed Point Theory, 6(2005), 157-229.

[3] R. Arab, The existence of fixed points via the measure of noncompactness and its application to functional-integral equations, Mediterr. J. Math., 13(2016), no. 2, 759-773.

[4] J.M. Ayerbe-Toledano, T. Domínguez-Benavides, G. López-Acedo, Measures of Noncompactness in Metric Fixed Point Theory, Birkhäuser Verlag, 1997.

[5] J. Banas, K. Goebel, Measure of Noncompactness in Banach Spaces, Lecture Notes in Pure ans Applied Math., Vol. 60, Marcel Dekker, 1980.

[6] J. Banas, M. Jleli, M. Mursaleen, B. Samet, C. Vetro (Editors), Advances in Nonlinear Analysis via the Concept of Measures of Noncompactness, Springer Nature Singapore, 2017. 
[7] M. Baronti, E. Casini, P.L. Papini, Diametrically contractive maps and fixed points, Fixed Point Theory Appl., 2006(2006), Art. ID 79075, 8 pp.

[8] L.E.J. Brouwer, Über Abbildungen von Mannigfaltigkeiten, Mathematische Annalen, 71(1912), $97-115$.

[9] J. Chen, X. Tang, Generalizations of Darbo's fixed point theorem via simulation functions with application to functional integral equations, J. Comput. Appl. Math., 296(2016), 564-575.

[10] G. Darbo, Punti uniti in trasformazioni a codomio non compatto, Rend. Semin. Mat. Uni. Padova, 24(1955), 84-92.

[11] B.C. Dhage, S.B. Dhage, H.K. Pathak, A generalization of Darbo's fixed point theorem and local attractivity of generalized nonlinear functional integral equations, Differential Eq. Appl., $\mathbf{7}(2015)$, no. $1,57-77$.

[12] J. Diestel, Geometry of Banach Spaces - Select Topics, Lecture Notes in Mathematics, vol. 485, Springer, New York, 1975

[13] J. Garcia-Falset, K. Latrach, On Darbo-Sadovskii's fixed point theorems type for abstract measures of (weak) noncompactness, Bull. Belg. Math. Soc. Simon Stevin, 22(2015), no. 5, 797-812.

[14] M.A. Geraghty, On contractive mappings, Proc. Amer. Math. Soc., 40(1973), 604-608.

[15] K. Goebel, B. Sims, More on minimal invariant sets for nonexpansive mappings, Proceedings of the Third World Congress of Nonlinear Analysts, Part 4 (Catania, 2000), Nonlinear Anal., 47(2001), no. 4, 2667-2681.

[16] L.S. Goldenstein, I.T. Gohber, A.S. Markus, Investigations of some properties of bounded linear operators with their q-norms, Ucen. Zap. Kishinovsk., 29(1957), 29-36.

[17] N. Hussain, Z. Kadelburg, S. Radenović, F. Al-Solami, Comparison functions and fixed point results in partial metric spaces, Abstr. Appl. Anal. 2012, Art. ID 605781 (2012).

[18] K. Kuratowski, Sur les espaces complets, Fund. Math., 15(1930), 301-209.

[19] R.D. Nussbaum, Some fixed point theorems, Bull. Amer. Math. Soc., 77(1971), 360-365.

[20] I.A. Rus, Generalized Contractions and Applications, Cluj-Napoca Press, 2001.

[21] B.N. Sadovskuii, On a fixed point principle, Funkt. Anal., 4(1967), no. 2, 74-76.

[22] J. Schauder, Der Fixpunktsatz in Funktionalräumen, Studia Math., 2(1930), 171-180.

Received: October 26, 2017; Accepted: December 13, $201 \%$. 
